\title{
Voltage Constrained Optimal Power Flow Based Using Genetic Algorithm
}

\author{
(Kekangan Voltan Aliran Kuasa Optimum Asas Menggunakan Algoritma Genetik) \\ Yassir* \& Teuku Hasannuddin
}

ABSTRACT

\begin{abstract}
Voltage constrained of Optimal Power Flow (OPF) is one of several methods to minimize fuel costs while maintaining system reliability constraints. In this study, Genetic Algorithm (GA) was applied to solve the problem of OPF. Active power generator, generator-buses voltages, transformer tap and injection capacitor are used as control parameters. Effectiveness of the proposed method was tested on IEEE 30 bus system and it has been compared to other optimization of power flow using other methods, for example the Evolutionary Programming (EP), Differential Evolution (DE) and Particle Swarm Optimization (PSO) methods. Simulation results of the three-phase voltage profile along the tested feeder using the proposed method provide better results than other mentioned methods. Before applying the proposed method, voltage profile on bus 12 (load-buses) is equal to 1.058 p.u, which is beyond the acceptable limits. However, after applying the proposed method, it improved the voltage profile at bus 12 to be within the acceptable limit, which is equal to 1.045 p.u.
\end{abstract}

Keywords: Optimal power flow; genetic algorithm; voltage constraint

\section{ABSTRAK}

Kekangan voltan bagi aliran kuasa optimum (OPF) adalah salah satu daripada beberapa kaedah untuk mengurangkan kos bahan bakar sambil mengekalkan kekangan kebolehpercayaan sistem. Dalam kajian ini, algoritma genetik diaplikasikan untuk menyelesaikan masalah OPF. Penjana kuasa aktif, penjana voltan-bus, tap pengubah dan kapasitor suntikan digunakan sebagai kawalan pembolehubah. Kaedah ini diuji pada kes IEEE 30 sistem bus dan dibandingkan dengan kaedah Evolutionary Programming (EP), Differential Evolution (DE) dan Particle Swarm Optimization (PSO). Hasil simulasi dengan menggunakan kaedah yang dicadangkan memberikan hasil yang lebih baik daripada kaedah yang disebutkan. Profil voltan sebelum pengoptimuman dengan kaedah yang dicadangkan terdapat pelanggaran voltan pada bus 12 (bus beban) iaitu sebanyak 1,058 p.u. Ini melebihi batas voltan bus beban yang diterima. Walau bagaimanapun, simulasi selepas pengoptimuman dengan kaedah yang dicadangkan boleh meningkatkan profil voltan pada bus 12 tidak melebihi batas yang dibenarkan iaitu sebanyak 1,045 pu.

Kata kunci: Aliran kuasa optimum; algoritma genetik; kekangan voltan

\section{INTRODUCTION}

In practical power system, the power plants are not located at the same distance from the center of loads and their fuel costs are different. Under normal operating conditions, the generated capacity of the generator is more than the total load demand and losses. In an interconnected power system, the objective is to find the actual and reactive power scheduling of each power plant in such a way due to minimize the operating cost. This means that the generator's actual and reactive power are allowed to vary within certain limits due to meet a particular load demand with minimum fuel cost. This is called the optimal power flow (OPF) problem (Saadat 1999).

OPF exploits all parameter controls to minimize the cost of operating the electric power system. For a common OPF, the normal constraints which included into the power flow are the network power balance at each node, bounds on all parameters, line-flow constraints, and others such as transformer tap ratios of parallel transformers (Allen \& Bruce 1996). Several optimization techniques have been applied to the OPF problem such as non-linear programming (NLP) (Mamoh et al. 1999a), linear programming (LP) (Mamoh et al. 1999b), and interior point method (IP) (Devaraj \& Yegnanarayana 2005).

The OPF problem is a complicated nonlinear which mixed the optimal problem with multi-objectives. The traditional optimization methods, such as linear and nonlinear optimization methods has obvious deficiencies of the dispersed parameter approximation, and these methods can not achieve the reality of global optimization. To overcome this problem, optimization methods such as evolutionary programming (EP) and differential evolution (DE) (Vaisakh \& Srinivas 2008), Particle Swarm Optimization (PSO) (Abido 2000), and the Genetic Algorithm (GA) (Devaraj \& Yegnanarayana 2005; Gaing \& Huang 2004; Bakirtzis et al. 2002; Moasheri 2011; Thakkar 2011) are applied. GA method can be used to solve OPF problems 
with non-convex curves. GA is not limited by the form of the characteristic curve generator, since this algorithm works by using probability methods, not deterministic. GA is also looking for a solution of the raised population. Therefore, GA can provide many solutions. Devaraj and Yegnanarayana (2005) makes use of the active power and power bus voltage as a control parameter. GA method (Gaing \& Huang 2004; Bakirtzis et al. 2002) utilizes roulette wheel selection for selection of parents. This selection system does not provide the rapid convergence results in certain cases such as in large systems. Results given are usually much different for each time the program is run.

In this paper, the decision parameters are represented in their natural form. Encoding uses real code of chromosomes with a fitness function that involves the generation cost function, limiting the minimum value total generation cost and the penalty function as restraints transmission line, reactive power and voltage magnitude of each bus, to obtain the minimum cost of grid operation. Parameter control involves the active power generation, generator-buses voltages, transformer tap setting and capacitors injection. To test the effectiveness of the proposed method, IEEE 30 bus system is selected.

\section{METHOD}

MATHEMATICAL MODEL OF OPTIMAL POWER FLOW

The objective function is given by the following fuel cost model (Mamoh 2001):

$$
F\left(P_{g}\right)=\sum_{i=1}^{N g} \alpha_{i}+\beta_{i} P_{g_{i}}+\gamma_{i} P_{g_{i}}^{2}
$$

with equality constraints representing the balance of active and reactive power are shown in equation (2) and (3).

$$
\begin{array}{ll}
P_{i}-P_{g_{i}}+P_{d_{i}}=0 & i=1, \ldots, N_{b} \\
Q_{i}-Q_{g_{i}}+Q_{d_{i}}=0 & i=1, \ldots, N_{b}
\end{array}
$$

Active and reactive power equations of each bus are given in equation (4) and (5).

$$
\begin{aligned}
& P_{i}=V_{i} \sum_{j=1}^{N_{b}}\left|V_{j} \| Y_{i j}\right| \cos \left(\theta_{i}-\theta_{j}+\psi_{i j}\right) \\
& Q_{i}=V_{i} \sum_{j=1}^{N_{b}}\left|V_{j} \| Y_{i j}\right| \sin \left(\theta_{i}-\theta_{j}+\psi_{i j}\right)
\end{aligned}
$$

the inequality constraints are as follow

- Voltage of each bus

$$
V_{i}^{\min } \leq V_{i} \leq V_{i}^{\max } \quad i=1 \ldots n_{b}
$$

- Active power generation

$$
P_{g i}^{\min } \leq P_{g i} \leq V_{g i}^{\max } \quad i=1 \ldots n_{g}
$$

- Reactive power generation

$$
Q_{g i}^{\min } \leq Q_{g i} \leq Q_{g i}^{\max } \quad i=1 \ldots n_{g}
$$

- Transformer tap setting

$$
T_{k}^{\min } \leq T_{k} \leq T_{k}^{\max }
$$

- Transmission line loadings

$$
S_{l} \leq S_{l}^{\max }
$$

where:

$$
\begin{aligned}
& F\left(P_{g}\right) \quad=\quad \text { Total fuel cost, as a function of } P_{g} \\
& P_{g i} \quad=\text { Active power generation at unit } i^{g} \\
& P_{d i}^{g i} \quad=\text { Active power demand at unit } i \\
& Q_{g i} \quad=\text { Reactive power generation at unit } i \\
& Q_{d i} \quad=\text { Reactive power demand at unit } i \\
& \alpha_{i}, \beta_{i}, \gamma_{i}=\text { Fuel cost parameters of unit } i \\
& N_{g} \quad=\quad \text { Number of generation units } \\
& N_{b} \quad=\quad \text { Total number of buses } \\
& V_{i}, V_{j} \quad=\quad \text { Voltage magnitude at buses } i \text { and } j \\
& \beta_{i^{\prime}}^{i^{\prime}} \beta_{j}^{j}=\text { Phase angles at buses } i \text { and } j \\
& P_{i} \quad=\text { Net active power injections at node } i \\
& Q_{i}=\text { Net reactive power injections at node } i \\
& P_{L} \quad=\text { Transmission losses } \\
& P_{D} \quad=\text { Total load demand } \\
& Y_{i j} \quad=\text { Magnitude of the complex admittance } \\
& \begin{aligned}
\theta_{i j}= & \text { Phase angle of the complex ad } \\
& \text { matrix element at position } i, j
\end{aligned} \\
& V_{i}^{\min }, V_{i}^{\max }=\text { Lower and upper bound on voltage } \\
& \text { magnitude at bus } i \\
& Q_{g i}^{\min }, Q_{g i}^{\max }=\text { Lower and upper bounds on reactive }
\end{aligned}
$$

\section{GENETIC ALGORITHM}

General Genetic algorithms are computational algorithms for optimization problems that is inspired by the theory of evolution to find solutions to a problem. There are many variations on Genetic Algorithms, one of which is the Genetic Algorithm for combination optimization problem, which is to get the value of an optimal solution to a problem that has many possible solutions (Suyanto 2005).

Genetic algorithm was first pioneered by John Holland from the University of Michigan in the 1960s, Genetic Algorithm has been widely applied in various fields. Genetic algorithms are widely used to solve optimization problems, despite the fact that also have a good ability in addition to optimization problems. John Holland stated that every problem in the form of adaptation (natural or artificial) can be formulated in genetic technology. 
Population Initialization A matrix with the value of each element in the form of a random number that raised between 0 and 1 . In this population, one line is one individual, each individual has a chromosome that is encoded as a control parameter, namely active power generator, generatorbuses voltages, transformer tap and capacitors injection corresponding minimum and maximum thresholds. Figure 1 shows the structure of chromosomes of GA that representing all control parameters. Chromosome coding scheme used in this study is a real number encoding as in (11) (Suyanto 2005).

$$
\mathrm{x}_{\mathrm{i}}=\mathrm{x}_{\text {min }}+\left(\mathrm{x}_{\text {max }}-\mathrm{x}_{\text {min }}\right) \cdot \text { chromosomes }
$$

\begin{tabular}{|l|l|l|l|l|l|l|l|l|l|l|l|}
\hline & & & & & & & & & & & \\
\hline $\mathrm{P}_{\mathrm{G} 2}$ & $\ldots$ & $\mathrm{P}_{\mathrm{GN}}$ & $\mathrm{V}_{\mathrm{Gl}}$ & $\ldots$ & $\mathrm{V}_{\mathrm{GN}}$ & $\mathrm{T}_{1}$ & $\ldots$ & $\mathrm{T}_{\mathrm{N}}$ & $\mathrm{Q}_{\mathrm{Cl}}$ & $\ldots$ & $\mathrm{Q}_{\mathrm{CN}}$
\end{tabular}

FIGURE 1. Chromosomes structure

Fitness An individual is evaluated based on a particular function as size performance. Function which is used to measure the value of degree of optimality of a chromosome is called the fitness function. The resulting value of the function indicates how the optimal solution is obtained (Suyanto 2005).

In the discussed cases in this study the objective is the minimization, the fitness is the reciprocal of the maximum value so that the fitness value is determined by a shared objective function. Objective function is to find the cost of the loss of generated power and networks with minimal restrictions are met so that if all restrictions on optimal power flow analysis are met, fitness can be calculated from these parameters. The inequality constraints involving the fitness are shown in equation (12).

$$
F=\frac{1}{\sum F\left(P_{g}\right)+\sum P_{\text {loss }}+\left(\sum P_{g}-P_{d}+\sum P_{\text {loss }}\right)+P E N A L T Y \_F U N C T I O N S}
$$

with:

$$
\begin{aligned}
\text { Penalty_Function }= & k \sum_{i=1}^{N g} f\left(Q_{g i}\right)+k \sum_{i=1}^{N} f\left(V_{i}\right) \\
& +k \sum_{m=1}^{N l} f\left(S_{l m}\right)
\end{aligned}
$$

Components consecutive penalty function is a function of the penalty for violation reactive power limits, voltage and transmission capacity constraints. Penalty value is expressed by equation (14).

$$
f(x)=\left\{\begin{array}{ccc}
0 & \text { if } & x^{\min } \leq x \leq x^{\max } \\
\left(x-x^{\max }\right)^{2} & \text { if } & x>x^{\max } \\
\left(x^{\min }-x\right)^{2} & \text { if } & x>x^{\min }
\end{array}\right\}
$$

Tournament Selection For simplicity, this method takes two individuals at random and then selects one of the highest fitness value to be parents first. The second parent is obtained from similar process. Tournament selection method is more complicated by taking $m$ individual at random. Then the highest individual fitness value is chosen as the first parent if the random number generated is less than a specified threshold value $p$ in the interval [0.1]. Selection of parents will be done at random from $m-1$ if the individual is no random number generated more than or equal to $p$. In the tournament selection, the parameter $m$ is the tournament size and $p$ is the probability tournament (Suyanto 2005).

Crossover Crossover process is one important operator in Genetic Algorithms. The methods and types of crossovers are done depend on encoding and issues raised. An individual that leads to a good solution can be obtained from crossover process two individuals (Suyanto 2005).

Crossovers turn worse if the population very small. In a small population, a chromosome that leads to the solution will spread to other chromosomes. To overcome this problem, the crossovers are controlled by certain probability $p_{c}$. It is performed only if a random number generated is less than the specified $p_{c}$. In general, the value of $p_{c}$ is set close to 1 , such as 0.8 (Suyanto 2005). In this paper, the default setting $p_{c}$ is 0.85 , to avoid the bad consequences of the process cross over of individual that leads to a solution is not lost.

Mutation Mutation is the process of changing the value of a chromosome. This mutation serves to replace a missing chromosome from the population due to selection and also allows the new chromosomes that do not appear in the initial population. For all chromosomes, if the random number generated is less than the mutation probability that has been determined, the chromosomal $P_{m u t}$ is changed to the opposite value (Suyanto 2005).

Elitisme Since the selection is conducted randomly, then there is no guarantee that an individual will always be the highest selected fitness value. In spite of the individual with the highest fitness value is selected, the individual may be damaged (fitness value down) because the process of crossover. To avoid loss of the individual during evolution, it needs to make one or more copies. This procedure is known as elitism (Suyanto 2005).

\section{ALGORITHM}

A voltage constrained optimal power flow using genetic algorithm can be described as follows. Flow chart of the proposed procedure is shown in Figure 2.

Step 1: Initialize of IEEE 30-BUS test system data of bus data including bus, load and generator. Line data and generator cost data.

Step 2: Initialize and run of genetic algorithm optimizer: Generating initial population 
Step 3: Decode the Chromosome as: $\mathrm{x}_{\mathrm{i}}=\mathrm{x}_{\text {min }}+\left(\mathrm{x}_{\text {max }}-\right.$ $\mathrm{x}_{\text {min }}$ )

Step 4: Run the power flow with parameter from decoded results are determined using Newton-Raphson method.

Step 5: Evaluate the individuals with specified restraints to seek fitness value:

Fitness $=\frac{1}{\Sigma F\left(P_{g}\right)+\Sigma P_{\text {loss }}+\left(\Sigma P_{g}-P_{d}+\Sigma P_{\text {loss }}\right)+\text { PENALTY } Y_{\text {FUNCTION }}}$

Step 6: Process the selection that implements the method of tournament selection, elitism, crossover and mutation.

Step 7: Repeat steps 3-6 until the maximum generation.

Step 8: Calculate the power plant, losses and total plant cost.

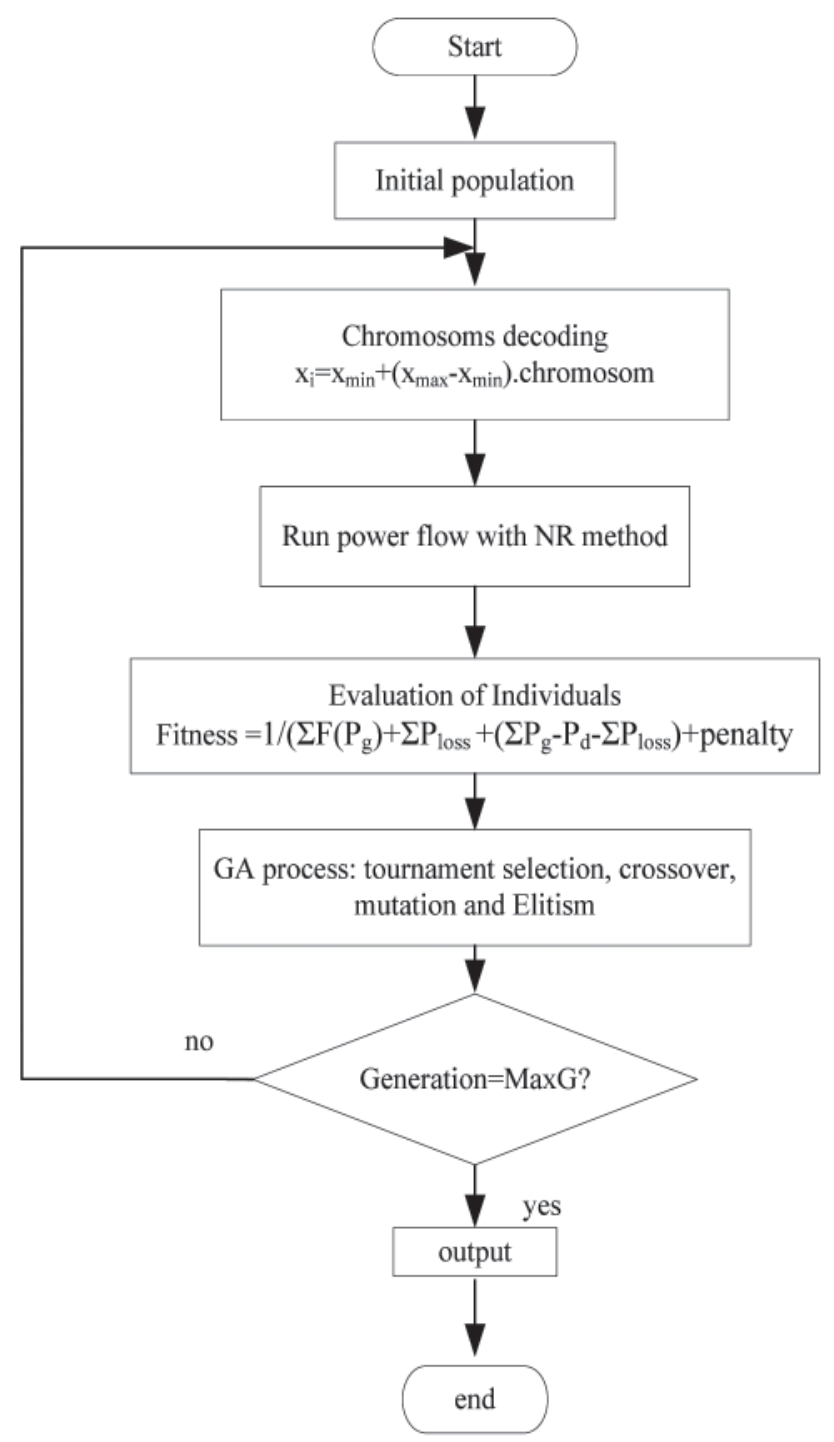

FIGURE 2. Flow chart of the proposed procedure

\section{RESULTS AND DISCUSSION}

To determine the effectiveness in solving OPF problem, the proposed method was tested with the IEEE 30 bus system. The system has six thermal plants, 30 buses and 41 lines with a total load of $283.4 \mathrm{MW}$. This system has 18 control parameters, namely: five units of the active power output, six generators bus voltage magnitude, four transformer tap settings and three capacitor injections. The lower and upper limits of voltage magnitudes in the IEEE system the specified are 0.95 p.u. - 1.05 p.u. and 0.9 p.u. -1.1 p.u. for load buses and generator buses, respectively. Table 1 shows the cost function and generator constraints IEEE 30 bus system. In this case, the simulation is done using the GA parameter with 18 parameters, 100 populations and 30 generations. Simulations are performed ten times and the best result is selected. Figure 3 shows that the total cost of generating the optimal value can be achieved before the 20 th generation. The simulation results of the proposed genetic algorithm method are compared with the DE, EP, and PSO method, respectively. Comparisons are also made with GA method which only uses active power generation and generator bus voltages as control parameters. Table 2 shows the results of the comparison. The total cost of the simulation results shows that the proposed method GA is less expensive compared with EP, DE, and PSO methods. The proposed method produces the minimum active losses compare other methods.

The best and worst results, average and standard deviation of ten times of the simulation are shown in Table 3. The Figure 4 shows voltage profile before optimization with the proposed methods, where violations voltage limits on buses 12 (load bus) that is equal to 1.058 p.u. It exceeds the limit load bus voltage of $5 \%$. Simulation after optimization

TABLE 1. Cost function and generator constraints

\begin{tabular}{cccccc}
\hline Generations & $\mathrm{P}_{\max }(\mathrm{MW})$ & $\mathrm{P}_{\min }(\mathrm{MW})$ & $\alpha$ & $\beta$ & $\gamma$ \\
\hline 1 & 200 & 50 & 0 & 2 & 0.00375 \\
2 & 80 & 20 & 0 & 1.75 & 0.0175 \\
3 & 50 & 15 & 0 & 1 & 0.0625 \\
4 & 35 & 10 & 0 & 3.25 & 0.0083 \\
5 & 30 & 10 & 0 & 3 & 0.25 \\
6 & 40 & 12 & 0 & 3 & 0.25 \\
\hline
\end{tabular}

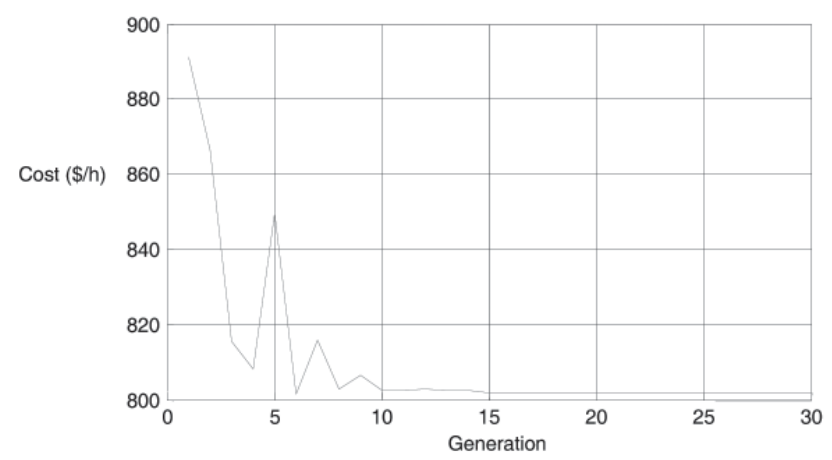

FIGURE 3. Total cost IEEE 30 bus system 
TABLE 2. Simulation result system IEEE 30 bus with GA method compared other method

\begin{tabular}{lccccc}
\hline Generator & EP & DE & GA & PSO & $\begin{array}{c}\text { GA } \\
\text { (proposed) }\end{array}$ \\
\hline P1(MW) & 175.58 & 177.30 & 179.39 & 173.68 & 174.02 \\
P2(MW) & 49.08 & 4918 & 48.83 & 49.10 & 48.39 \\
P5(MW) & 14.74 & 12.24 & 21.84 & 21.81 & 21.61 \\
P8(MW) & 11.18 & 11.19 & 21.75 & 23.30 & 21.99 \\
P11(MW) & 21.27 & 21.23 & 12.05 & 13.88 & 13.42 \\
P13(MW) & 20.99 & 21.24 & 12.36 & 12.00 & 13.00 \\
Total Cost (\$/h) & 802.65 & 802.23 & 803.05 & 806.36 & 801.60 \\
Losses (MW) & 9.47 & 9.53 & 9.48 & 10.37 & 9.05 \\
\hline
\end{tabular}

with the proposed method show in the Figure 5 can improve the voltage profile at bus 12 does not exceed the permitted limit is equal to $1.045 \mathrm{pu}$.

TABLE 3. Best result, average and deviation standard

\begin{tabular}{lc}
\hline Simulation result & Cost $(\$ / \mathrm{h})$ \\
\hline Worst & 803.50 \\
Best & 801.60 \\
Average & 802,47 \\
Standard Deviation & 0,63 \\
\hline
\end{tabular}

\section{CONCLUSION}

In this research, the genetic algorithm method is proposed to solve the optimal power flow problem. The IEEE 30 bus system is selected, and the simulation of has been done. It can be concluded that the proposed method showed better results than the method of DE, EP, and PSO which has been developed previously. Simulation after optimization with the proposed method can improve the voltage profile at bus 12 does not exceed the permitted limit is equal to 1.045 p.u. It is not exceeds the limit load bus voltage. On IEEE 30 bus system, the convergence has been achieved before the 20th generation. It indicates that the proposed method is able to find the optimal value quickly.

\section{LIST OF SYMBOLS}

$\alpha_{i}, \beta_{i}, \gamma_{i}=$ Fuel cost parameters of unit $i$

$\theta_{i j} \quad=$ Phase angle of the complex admittance matrix element at position $i, j$

Pc $=$ crossover probability

p.u $=$ per unit

$\theta_{i}, \theta_{j} \quad=$ Phase angles at buses $i$ and $j$

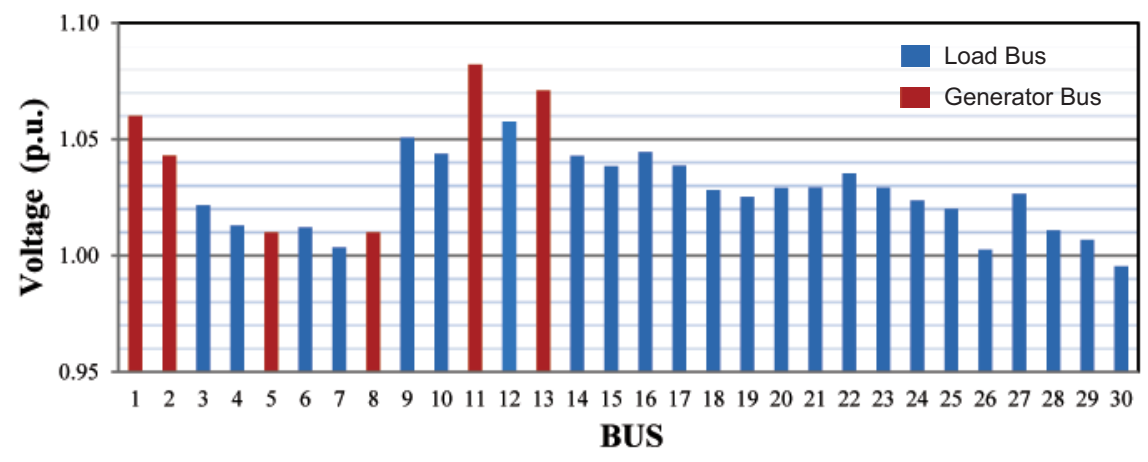

FIGURE 4. Voltage profile before optimization

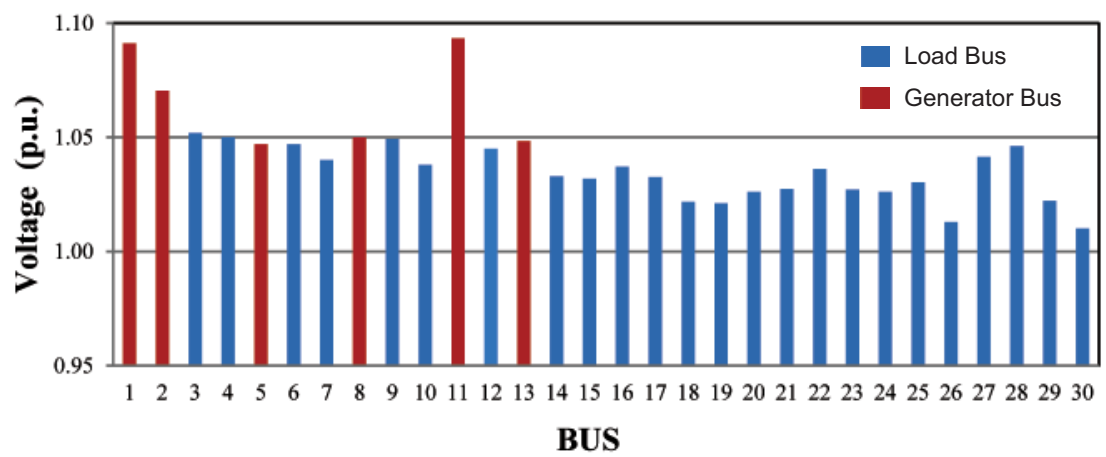

FIGURE 5. Voltage profile after simulation with the proposed method 
REFERENCES

Abido, M. A. 2000. Optimal power flow using particle swarm optimization. Electrical Power and Energy System 24: 563-571.

Allen, J. W. \& Bruce, F. 1996. Power Generation, Operation and Control. John Wiley \& Sons, Inc.

Bakirtzis, G., Biskas, P. N., Zoumas, C. E. \& Petridis, V. 2002. Optimal Power Flow by Enhanced Genetic Algorithm. IEEETransaction on Power System 17(2): 229-236.

Devaraj, D. \& Yegnanarayana, B. 2005. Genetic-algorithmbased Optimal Power Flow for security enhancement. IEE Proceding Gener. Transm. Distrib. 152(6): 899905.

Saadat, H. 1999. Power System Analysis. New York: WCB McGraw-Hill.

Gaing, Z. L. \& Huang, H. S. 2004. Real-coded mixed-integer genetic algorithm for constrained optimal power flow. IEEE Region 10 Conference, Taiwan 3: 323-326.

Mamoh, J. A. 2001. Electric power system applications of optimization. Marcel Dekker, Inc.

* Yassir \& Teuku Hasannuddin Jurusan Teknik Elektro

Politeknik Negeri Lhokseumawe

Aceh, Indonesia

*Corresponding author; email: yassirasnawi@gmail.com

Received date: $24^{\text {th }}$ November 2014

Accepted date: $1^{\text {st }}$ April 2015
Mamoh, J. A., Adapa, R. \& El Hawary, M. E. 1999a. A review of selected optimal power flow literature to 1993, part I: Nonlinear and quadratic programming approaches. IEEE Trans. Power Syst. 14(1): 96-104.

Mamoh, J. A., Adapa, R. \& El Hawary, M. E. 1999b. A review of selected optimal power flow literature to 1993, part II: Newton, linear programming and interior point method. IEEE Trans. Power Syst. 14(1):105-111.

Moasheri, S. R. 2011. Optimal Power Flow based on Modified Genetic Algorithm. IEEE 978-1-4244-6255-1/11.

Suyanto. 2005. Algoritma Genetika dalam MATLAB. Andi Yogyakarta.

Thakkar, V. C. 2011. Optimal Power Flow using Genetic Algorithm Technique. National Conference on Recent Trends in Engineering \& Technology.

Vaisakh, K. \& Srinivas, L. R. 2008. Differential Evolution based OPF with Conventional and Non-Conventional Cost Characteristics. Power System Technology and IEEE Power India Conference, India: 1-9. 